\title{
Spatial Social Network Analysis: Program Pengembangan Usaha Agribisnis Perdesaan (PUAP) or an Exertion Development Program in Supporting the Region Revitalization Development
}

\author{
Bentar Priyopradono, Danny Manongga, Wiranto Herry Utomo \\ Faculty of Information Technology, Satya Wacana Christian University, Salatiga, Indonesia \\ Email: bentarpriyopradono@yahoo.com,dmanongga@gmail.com, wiranto.utomo@staff.uksw.edu \\ Received February 18, 2013; revised March 19, 2013; accepted April 13, 2013
}

Copyright (C) 2013 Bentar Priyopradono et al. This is an open access article distributed under the Creative Commons Attribution License, which permits unrestricted use, distribution, and reproduction in any medium, provided the original work is properly cited.

\begin{abstract}
As the exertion development (PUAP) develop in Rejang Lebong Regency in Bengkulu province which had been started since 2008 by giving a kind of fund aid called Bantuan Langsung Masyarakat (BLM PUAP), to Gapoktan (Gabungan Kelompok Tani) or an organization of farmers such by giving some money as the capital used for 1) food plant cultivation, horticulture, animal husbandry, plantation, and 2) non-cultivation exertion such as; home industry of agriculture, small marketing scale and another agriculture exertion. By the approach which had been done is hoped to get the important result, on the other way the role of analysis factor (Social Network Analysis) from all undertaking stakeholders programs PUAP to be relevance steps aimed to understand the relation or connectivity from all factors in the network and also the role of factor inside the network itself be the relevance steps in arranging the strategy and work intention from the realization stage of PUAP program for the continuity of the realization program in the future (finding the good strategy) which aimed to develop the program of PUAP in Rejang Lebong Regency in Bengkulu Province, and to be a reference from doing the program as a national program in Indonesia.
\end{abstract}

Keywords: Exertion Development Program (PUAP); Social Network Analysis; Agriculture; Horticulture

\section{Introduction}

Based on the data of Badan Pusat Statistik (BPS) or Statistical Central Board of Republic of Indonesia, since March 2011 to March 2012 the number of poor society in Indonesia is 29.13 millions or $11.96 \%$, from this number, around 18.48 millions live in villages with the main living in the agriculture sector. Commonly the societies in the villages are in the micro scale that have only small living field around 0.3 hectare. The poverty in remote area is the national main problem that must be something important to pay attention on to overcome and cannot be delayed but has to be the first priority in developing social welfare. Therefore, the economic national development agriculture-based in villages will give the good result such as decreasing the societies' poverty. The basic problem faced by the farmers in Indonesia is lacking of source of financial capital, market and technology, and the farmers' organization which is still weak. That is why overcoming the societies' poverty is the important part of realization in long term development planning and global agreement to reach Millennium development Goal. Indonesian Agriculture Ministry since 2008 have started the exertion development program for the society in remote area (PUAP) under the coordination of the PNPM program (National program for independent society) and involved in developing society organization program.

PUAP Program which was implemented starting in 2008 , with the approaches that have been done, are expected to produce a important result in developing the work of PUAP program have facilitated such as; providing Penyelia Mitra Tani (PMT), co-workers investigator, and technology investigating by Balai Pengkajian Teknologi Pertanian (BPPT). Through investtigating, developing and consolidating the way societies' economic development based on the agriculture in the place, giving financial capital through the Gapoktan program who have production and marketing exertion and saving and loan association unit. 
On the other way the role of analysis factor (Social Network Analysis) from all undertaking stakeholders programs PUAP to be relevance steps aimed to understand the relation or connectivity from all factors in the network and also the role of factor inside the network itself be the relevance steps in arranging the strategy and work intention from the realization stage of PUAP program for the continuity of the realization program in the future (finding the good strategy), one of the problem is lacking of co-worker investigator who responsible to accompany the farmers, farmers' organization and Gapoktan in implementing PUAP to support the region revitalization development, therefore in order to reach this goal it is interesting to be observed. Social Network in implementing PUAP is done to more understand the information, knowledge sharing and knowledge building between co-worker investigator, Penyelia Mitra Tani (PMT) and Farmer Organization (Gapoktan).

\section{Literature Review}

\subsection{Social Network}

Network is an association of relations between nodes [1], formally network has some objects called nodes, a simple example of network can be found and seen is on the existence of the society, the existence of the society can be seen as a network, social relationship between one individual and another and really complex [2], in a network symbolizing an interaction between nodes or actors, basically the interaction or relationship happen can be categorized become a symmetrical or non-directional relationship (two ways relationship) and directional relationship (one way relationship). We can see this thing in the example of two nodes or actors ( $\mathrm{X}$ and $\mathrm{Y}$ ). $\mathrm{X}$ and $\mathrm{Y}$ are interested one another as symmetrical or non-directional relationship. As the continuation, if $\mathrm{X}$ likes $\mathrm{Y}$ can be called as directional relationship [1]. In the society we can find the network and social network [3]. Social network itself meant as small world phenomenon who comes from observation that each individual often connected by the short introduction chain, the relation chain which is accumulated to form a complex social network [2]. Simply the social network can be descried based on the components that form it like [2]: 1) A group of people, objects or events at least 3 who play role as terminal. Commonly interpreted by using dots that is called nodes or actor, 2) as a bound who relates one dot to another dots in network. This bound is interpreted by using lines which is an access or a way. This bound include a visible bound or an invisible bound. Usually this bound happen and identified by network relation or boundaries, and 3) flow, it is symbolizing by an arrow in the diagram. It describes something that flows from one dot to another dot, through the direction that relates every dots in the network.

\subsection{Social Network Analysis}

In social sciences, social network analysis has become a strong methodology beside the statistic, network concept that has been definite, tested, an applied in research tradition in all social science, starting from anthropology, sociology, business administration and history [4]. Social Network Analysis (SNA) is a tool to map the important knowledge relationship between individuals [5]. SNA as an approach used to do social research to find the vertical and lateral information, indentify the sources and aim to find the limitation about the resources [6], SNA is developed to understand the relationship (ties/edge) from actors (nodes/points) in a system with 2 focuses such as; actors and the relation between actors in particular social context. This focus helps the understanding about how the actors position can influence the access towards the resources such as; materials, financial capital and information. This case shows that the economic activities are related to the social structure which is finally goes to the concept of financial capital social. Information as a the most important resources that flows in a network so the SNA often implemented to identified the information flows [6]. Theoretically, by indentifying the information flows can help to develop the strategy that can encourage the actors to share the information rather than they have to create a new strategy $[7,8]$. When the actors access the recourses they have, the actors will form a cluster, where the actor with the best position will get more information compared to the others. Usually the actor who has access from many resources will join in many clusters, and it can give more power because they act as mediator to those who have few contacts and access. Something has to be observed is the information flow does not need to be same, whish meant the hierarchy is formed based on the actor's position in the network. Network is not only giving the access to the sources, but also giving the access to another source that can help to give value towards the sources itself. This shows that actor can arrange the social network to maximize their benefit by approaching the sources and the opportunities available $[7,8]$.

\subsection{Measurements in Social Network Analysis}

In social network analysis, there are some measurement terminologies which are often used, such as:

\section{Density and Eigenvector}

Density and Eigenvector as a proportion in all relations that a network has, by using this density measurements can get the information about the number of relation which is built by each actor in a network. By knowing the average score (mean) and the total number of relationship (Sum) from the relationship of actors in the 
network, we can see the strength of relation which is possible happen in the whole network. The eigenvector approach as an effort to find out the most central actor in the whole network. Eigenvalue explains the location of actors on each dimension or the globally distance relationship. Eigenvector itself as an association of eigenvalue. Eigenvector here seeing to the global distance aspect between actors $[9,10]$.

\section{Centrality, Power and Degree}

Centrality is one of the most important conceptual tools and widely used for analyzing social networks, almost all empirical studies attempting to identify the most important actors in the network, centrality is a measure to show how important an actor in a network [11]. Implications of node/actor at the center of a network is the actor has a stronger capability in connecting members of the other network [9]. Dengre node in a network describing the relationship actor/node, the degree there are two types of nodes that link in-degree (number of connection actor/node as the target) and out-degree (number of connection actor/node as the source). There are 5 types of node connectivity between actors/nodes in the degree of which node 1) "isolate" means the actor/node has no link/connection to actor/node, 2) nodes "transmitter" actor/nodes only have a link to the outside and there is no link to the inside, 3) nodes "receivers" actor/nodes have only just received a link to into the connectedness of actors/other node, 4) node "carrier" actor/node that has a link in-degree and out-degree equal to 1 (one), and 5) the node "ordinary" is a normal node where there is a link to the outside and into the actor/node $[12,13]$. In general, to measure the role and influence of the actors in a network can be done by looking at the 3 (three) terminology centrality measures, namely: Degree centrality, Closeness centrality and Betweeness centrality [9]:

1) Degree centrality is the degree of the presence and position of actors in a social network. Degree centrality approach is divided into two $[1,10]$.

a) In-Degree: an actor with a high degree show in the role of an actor is very important (prominent actor). This is because many actors are trying to get in touch with them.

b) Out-Degree: an actor who has his degree out of high implies a position of an actor within a social network as an Influential actors (actor effect). This demonstrates the ability of an actor is able to exchange information with the other actors and other actors also recognize and accept his views. Mathematically, Degree centrality for a node/actor can be calculated with the formula:

$$
C_{D}\left(p_{i}\right)=\sum_{k=1}^{N} a\left(p_{i}, p_{k}\right)
$$

where, $a\left(p_{i}, p_{k}\right)=1$, if there is a direct tie between $p_{i}$ and $p_{k}$ dan $i \neq k$.
2) Closeness centrality is a measure of how far the information can be spread from one actor to the other actors. In addition, Closeness centrality can also show the distance between the actors against the other actors in a network. The higher the value the closeness of the actors, showing increasingly easy for the actor to disseminate information in the network. Likewise, if the value of proximity is low, then the distance the actor with other actors is far enough that the dissemination of information from informants is difficult actor to another actor. Approach for two closeness centrality in the in-closeness and out-closeness centrality centrality $[13,14]$. Mathematically, Closeness centrality for a node/actor can be calculated with the formula:

$$
C_{c}\left(p_{i}\right)=\frac{N-1}{\sum_{k-1}^{N} d\left(p_{i}, p_{k}\right)}
$$

where, $N$ is the number of node or actors in a network and $i \neq k$.

Resiprokalitas of geodesic distance $d\left(p_{i}, p_{k}\right)$, which is the shortest path between nodes pi and other actors also affordable. With these pathways may be a measure of how far the information can be from one node/actor to another actor.

3) Betweeness centrality is a measure that includes how much a node/actor is able to control/control the flow of information between actors in the network. Betweeness high centrality of an actor's actor showed a great capacity to facilitate the interaction between the actors connected, mathematically. Betweeness centrality can be calculated with the formula:

$$
C_{B}\left(p_{i}\right)=\sum_{j=i}^{N} \sum_{k=1}^{j-1} \frac{g_{j k}\left(p_{i}\right)}{g_{j k}}
$$

where, $g_{j k}$ is the total number of geodesic path connecting $p_{j}$ and $p_{k}$, and $g_{j k}\left(p_{i}\right)$ is the number of geodesic path includes $p_{i}$.

\section{Spatial Network Analysis}

Spatial social network analysis tries to see and discuss how an actor's position in geographical space/regions can be analyzed along with their position in the social network. Spatial Social Network explains the important role of spatial concepts, such as distance, location, proximity, environmental, and regional influence in society, social behavior is a geographically specific context, and that space and society formed with each other, then it requires merging multiple spatialities into the analysis social network $[15,16]$. Spatial location of social network analysis to identify the actors in the social network (social network), by entering the simultaneous position and place the actors in the relationship in a network, social 
network facilitates spatial analysis of social behavior in the context of simultaneous and related network position and relative location in geographical space[15].

\section{Agribusiness Rural Business Development}

Rural Agribusiness Development (PUAP) is a program of the Ministry of Agriculture of the Republic of Indonesia breakthrough, the program began in 2008, has been implemented in 20,426 villages in 417 districts and 33 provinces in Indonesia. One of the main activities are distribution of funds PUAP Direct Community Assistance (BLM) to Gapoktan (Association of Farmers Group) in the form of capital gain that is used to: 1) cultivation of food crops, horticulture, livestock, crops, and 2) nonfarming businesses include venture farm household industries, small scale marketing and other business-based agriculture. The main approach Rural Agribusiness Development (PUAP) is expected to produce a resultant significant, as well as the main indicator of the successful implementation of the program PUAP namely: a) Empowerment Gapoktan (Association of Farmers Group), b) working capital assistance for productive activities, c) Agribusiness, d) Regional, e) Institutional and f) Empowering communities in a participatory manner. To improve performance, Gapoktan PUAP has much facilitated, such as the provision of expert Supervisor Mitra Tani (PMT), a companion extension (PP), technology assistance by the Center for Agricultural Technology (BPTP), coaching by the provincial and district governments.

1) Combined Farmers Group (Gapoktan) is a collection of some Farmers Group (Poktan) who join and work together to improve economies of scale and opera tionalefficiency. Gapoktan PUAP institutional management is the Ministry of Agriculture grant of 100 million dollars for capital strengthening, so that members can Gapoktan develop economically productive agribusiness. The pattern of development PUAP pursued through facilitation/ mentoring, sharpening and strengthening of community-based economic development direction of local agricultural resource potential. Gapoktan that will be the goal of providing venture capital is Gapoktan that have production and marketing efforts, and the Savings.

2) Extension agricultural extension escort is assigned by the Regent/Mayor or his representative to assist farmers, farmer groups (Poktan) and Gapoktan PUAP implementation, with tasks: a) to identify the economic potential of village-based agriculture, b) provide technical guidance rural agri-business including the marketing of the business, c) help solve the business problems of farmers/farmer groups, as well as during the preparation of the documents accompanying Gapokan PUAP and institutional growth process, d) Conducting training agri- business and economically productive suitable village potential and e) Helps to facilitate ease of access to the means of production, technologi.

3) Supervisor Mitra Tani (PMT) are individuals who have expertise in the field of microfinance recruited by the Ministry of Agriculture: a) Supervise and advocacy processes to Gapoktan institutional growth through the development PUAP Instructor Companion, b) Conducting regular meetings with Extension Complementary and Gapoktan, c) Conduct preliminary verification of the RUB and other administrative documents and d) Implement escorts utilization of funds managed by the BLM PUAP Gapoktan.

Rural Agribusiness Development (PUAP) aims to: a) reduce poverty and unemployment through the growth and development of agribusiness activities in rural areas in accordance with the potential of the region, b) improve the capability of agribusiness, Gapoktan Board (Association of Farmers Group), Extension Companion (PP) and Supervisor Mitra Tani (PMT), c) to empower farmers and rural economic institutions for the development of agribusiness activities and d) improving the institutional function of peasant economy into a financial institution or a partner network in order to access to capital.

\section{Research Objectives}

Problems faced at the stage of preparation and strengthening program implementation PUAP, one of which is still less optimal Supervisor Mitra Tani (PMT) and a companion extension assigned to assist farmer groups and Gapoktan (Farmers Association) in the implementation of programs to support the revitalization PUAP increase local food, therefore in order to meet these expectations, interesting to study. Mapping social networks of all program stakeholders PUAP a relevant step, in-depth understanding of information flow, knowledge sharing and knowledge building among extension companion (PP), Supervisor Mitra Tani (PMT) and Gapoktan Patronage (Association of Farmers Group), with the goal of understanding the connectedness or Connectivity of the actors, as well as view the role of actors in the networkand external elements determine what influence the sustainability of the program in the future PUAP. It's all become a necessity in order to develop a strategy and planning phase of the program of work of PUAP for the sustainability of the program in the future.

\section{Related Work}

This study tries to combine lifting and social network analysis (SNA) with spatial analysis methods, they see that the social sciences seem to have clear linkages with geography, the compatibility of the techniques of social 
network analysis (SNA) with a geographic network theory, but the theory was widely repudiated, due to lack of nuance or geographical considerations spatialities strength and other social relationships in a social network [17, 18]. They see and are aware of these shortcomings, and they try to explore the technique of structural equivalence in social networks as a means to combine geographic information in social network analysis, social theory integrates geography and spatial analysis techniques. In particular, they discuss how an actor's position in geographical space can be analyzed simultaneously with the position in the social network. In their study, they compared the relationship and competition among criminal street gangs in Los Angeles with the intercomnectedness gang geographically, to identify the gang by geography and competitive position in the network, which helps in understanding the overall context of gang violence [18].

\section{Data Collection}

Data samples of respondents are taken under consideration for representativeness of the sample to the population on the implementation of the Rural Agribusiness Development Program (PUAP), obtained information relating to the composition of the 95 respondents. Based on the results of questionnaires and interviews were selected on the implementation of the program in the district PUAP Rejang Lebong Bengkulu province. All data sample of respondents who becomes the object of this study, a combination of the implementation of the Rural Agribusiness Development Program (PUAP) Rejang Lebong district, as shown in Table 1, all respondents have age between 28 years to 59 years, of the 95 respondents who gave information at the district/city consists of 10 respondents among 3 people interrupters Mitra Tani (PMT) conducting supervision and advocacy Gapoktan institutional growth process (Joint Farmers Group), 7 person staff and institutional development programs BP4K (Executive Agency for Agricultural Extension, Fisheries and Forestry). While working at the regional district/village staff and respondents are agricultural ex-

Table 1. List of target population, population sample survey and research.

\begin{tabular}{|c|c|c|}
\hline Region & Department & Respondent \\
\hline District & $\begin{array}{l}\text { Executive Agency for } \\
\text { Agricultural Extension, } \\
\text { Fisheries and Forestry } \\
\text { (BP4K) }\end{array}$ & $\begin{array}{l}3 \text { person } \mathrm{PMT} \text { and } 7 \\
\text { person staff } \mathrm{BP} 4 \mathrm{~K}\end{array}$ \\
\hline $\begin{array}{l}\text { Work } \\
\text { Area }\end{array}$ & $\begin{array}{l}\text { Agricultural Extension } \\
\text { Center(BPP) }\end{array}$ & $\begin{array}{c}61 \text { Extension Companion } \\
\text { (PP), } 14 \text { Staff BPP, and } 10 \\
\text { head of BPP }\end{array}$ \\
\hline Total & & 95 respondents \\
\hline
\end{tabular}

tension in $10 \mathrm{BPP}$ (Agricultural Extension Center) consists of 61 Extension Companion (PP), 14 Staff BPP (Agricultural Extension Center), and 10 head of BPP (Agricultural Extension Center). In line with the respondent sample taken under certain considerations to representativeness of the sample to the population PUAP stakeholders, obtain information related to the composition of the respondent. Based on the deployment of 95 questionnaires and interviews of 95 respondents were selected, obtained the following information:

\section{Analysis and Discussion}

The results of processing the data sample respondents obtained results Social Network visualization and statistical description of the relationship of actors involved in the implementation of developing a Rural Agribusiness (PUAP) in Rejang Lebong regency in Bengkulu province, the data processing and analysis process in this study carried out with the help NetMiner4 applications. To be able to see the depth of social network visualization, the following will be discussed relationships and interactions are built and woke up from the actors, the views of some of the analysis in Social Network Analysis.

\subsection{Centrality or Prominent Actors in the Network}

\subsubsection{Degree Centrality}

This stage tries to see, measure and identify the role of the actor's most important/influential (power) of the actor/node in the network, the actor who became the center of a network is the actor has a stronger capability in connecting members in the other network [19,20], visualization results can be seen in the sociogram in-degree centrality and out-degree centrality in Figures $\mathbf{1}$ and $\mathbf{2}$. The results of the calculation of degree centrality of the total 95 respondents, it can be seen whether the tendency of each actor/nodes have the ability to affect the network (network) in general, can be seen from the value index centraliry network degree, in-degree and out-degree. If seen in Table 2 . centraliry degree value network in-degree index: $22.832 \%$ and network centraliry degree outdegree index: $31.526 \%$, this indicates that the centralized network (network centrality) are keselurahan low, below $50 \%$. This indicates that the influence/power of each actor/nodes in the network are not so varied, every actor/ nodes tend to lack the ability to influence the general network.

The results of the calculations in-degree centrality, there are actors/nodes that have a value in the highest-degree centrality of them 1) Busroni, A.md with values $0.266,2$ ) Bambang PT, S.TP the value of 0.2128 , and 3) Suswandi, SE with a value of 0.1489 has the same value as the actor Rindra $\mathrm{P}, \mathrm{SP}$, of the four actors can be 


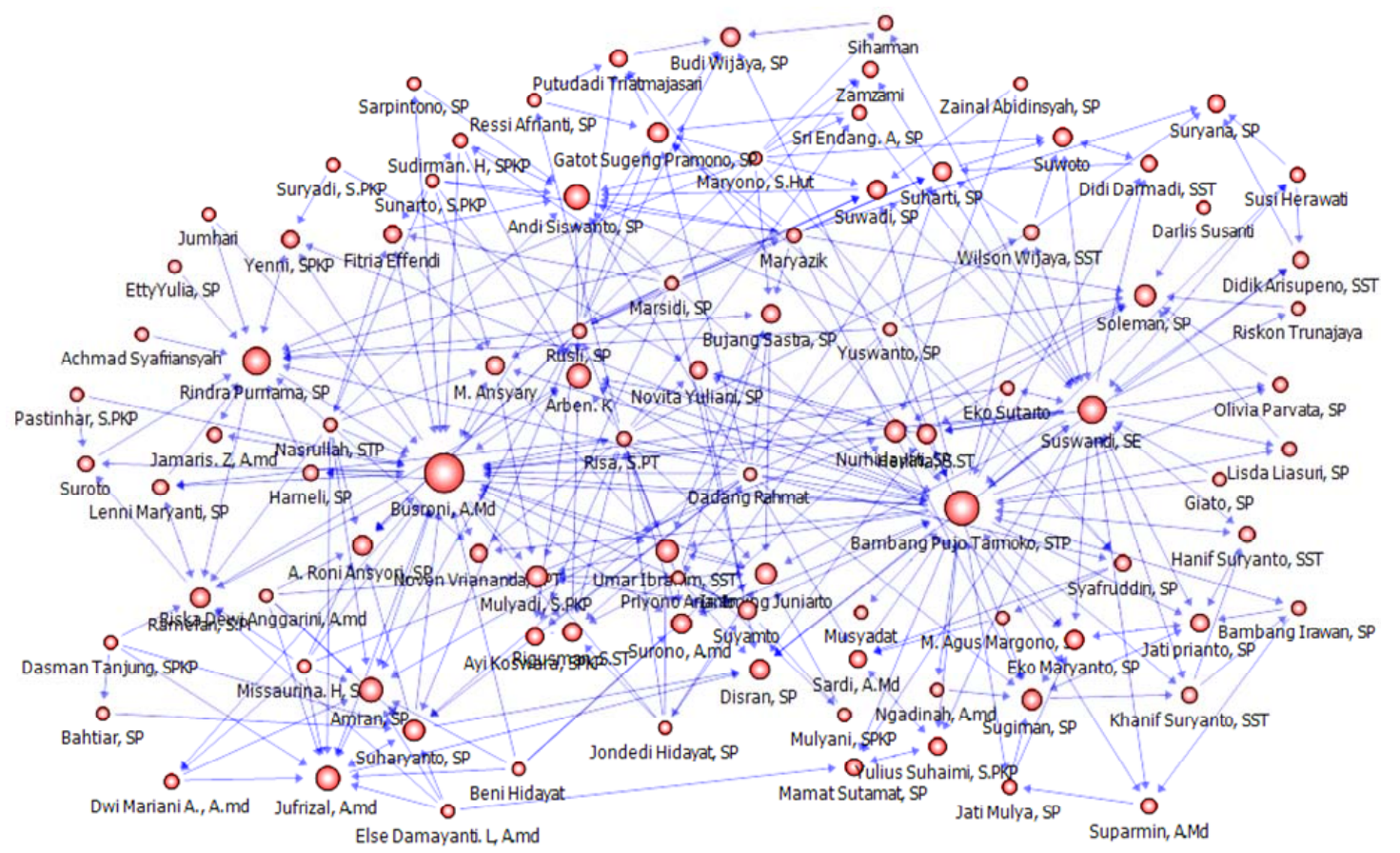

Figure 1. Sociogram in-degree centrality.

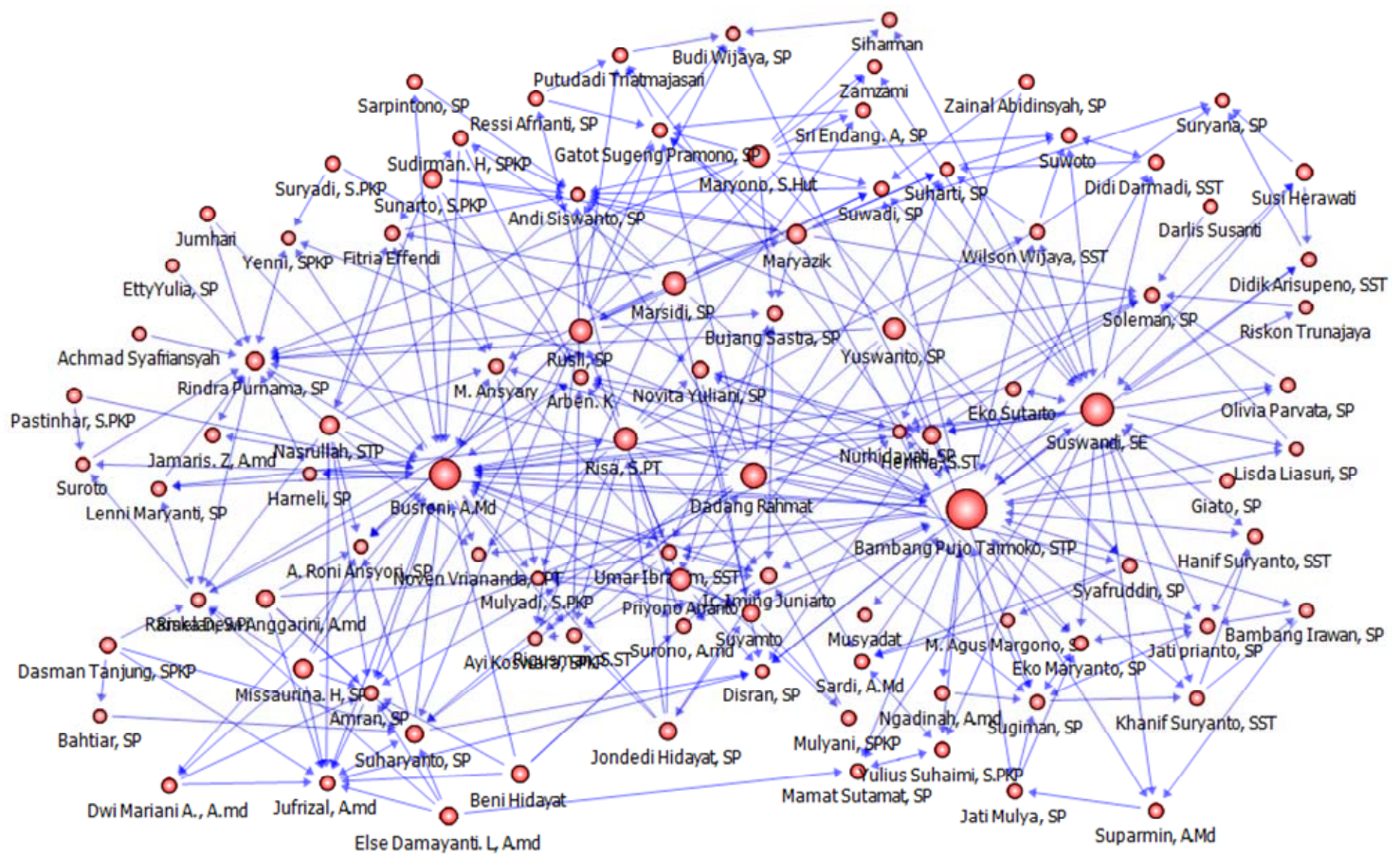

Figure 2. Sociogram out-degree centrality.

termed as the focal actor of the network and the important actors (prominent actors), this illustrates that many actors/nodes within the network trying to make contact with them.

The results of the calculation of out-degree centrality, there is actor/node that has a value of the highest out-degree centrality of them 1) Bambang PT, S.TP with a value of $0.3511,2$ ) Suswandi, SE with a value of 0.2553, and (2) Busroni, A.md with a value of 0.2447 , this case illustrates that the third actor is the most influential on the network because they have the ability to exchange information and the three actors have an important role in the network because they are the center/ hub for the exchange of information. 
Table 2. Distribution of degree centrality scores.

\begin{tabular}{ccc}
\hline \multirow{2}{*}{ Measures } & \multicolumn{2}{c}{ Value } \\
\cline { 2 - 3 } & In-Degree Centrality & Out-Degree Centrality \\
\hline Mean & 0.042 & 0.042 \\
Std. Dev. & 0.045 & 0.055 \\
Min & 0 & 0 \\
Max & 0.266 & 0.351 \\
\hline \multicolumn{3}{c}{ Network Degree Centrality Index } \\
\hline (In) & $22.832 \%$ \\
(Out) & $31.526 \%$ \\
\hline
\end{tabular}

\subsubsection{Closeness Centrality}

Closeness centrality is based on the total distance between one point and all other nodes, where distances are greater closeness centrality produces low scores. The closer a node to another node information more easily be achieved, the higher its centrality $[12,13,20]$. The results of the sociogram in-closeness centrality and out-closeness centrality can be seen in Figures $\mathbf{3}$ and $\mathbf{4}$ which is a visualization of the entire data sample is ob- tained from a total of 95 respondents.

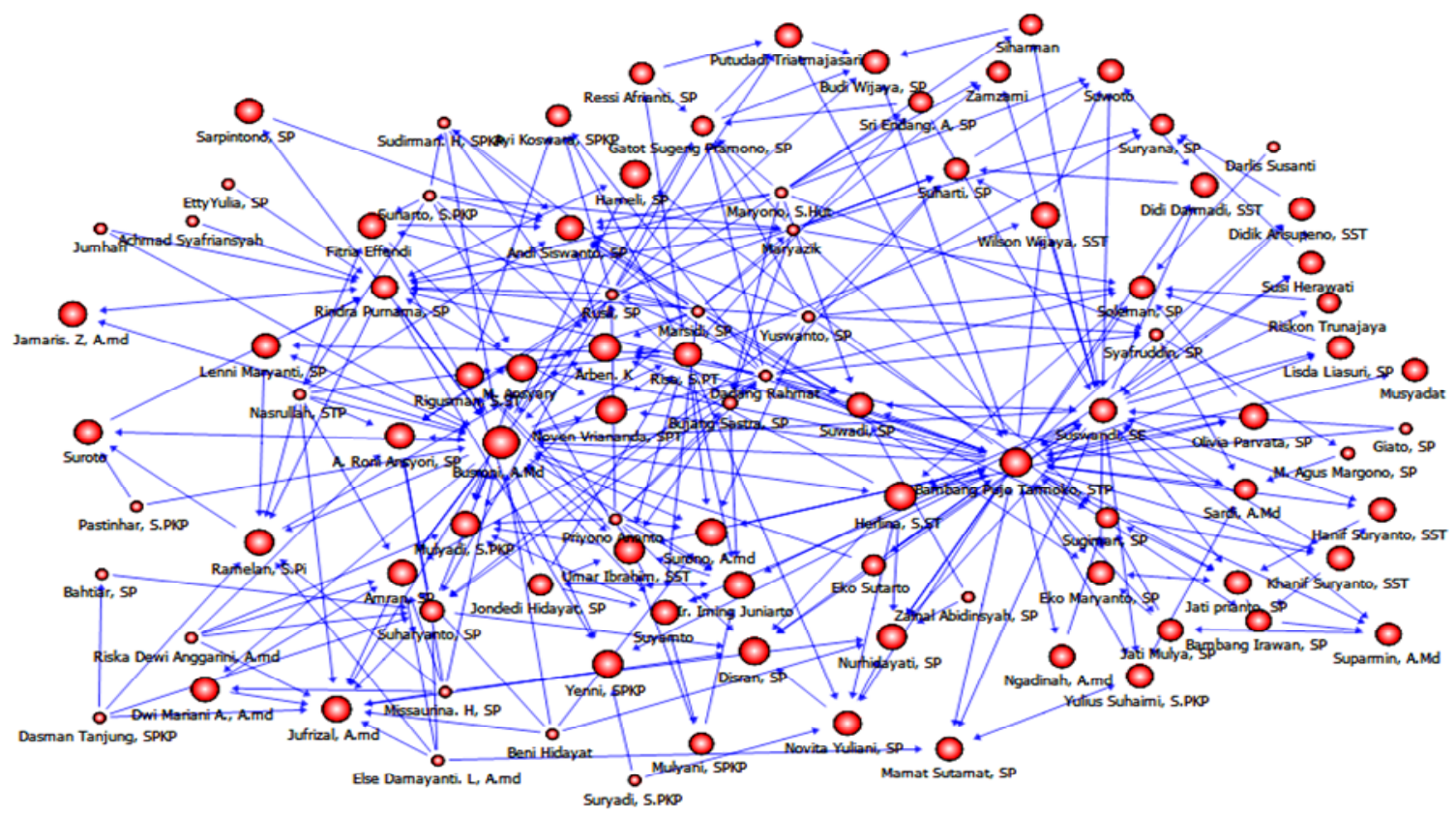

Figure 3. Sociogram in-closeness centrality.

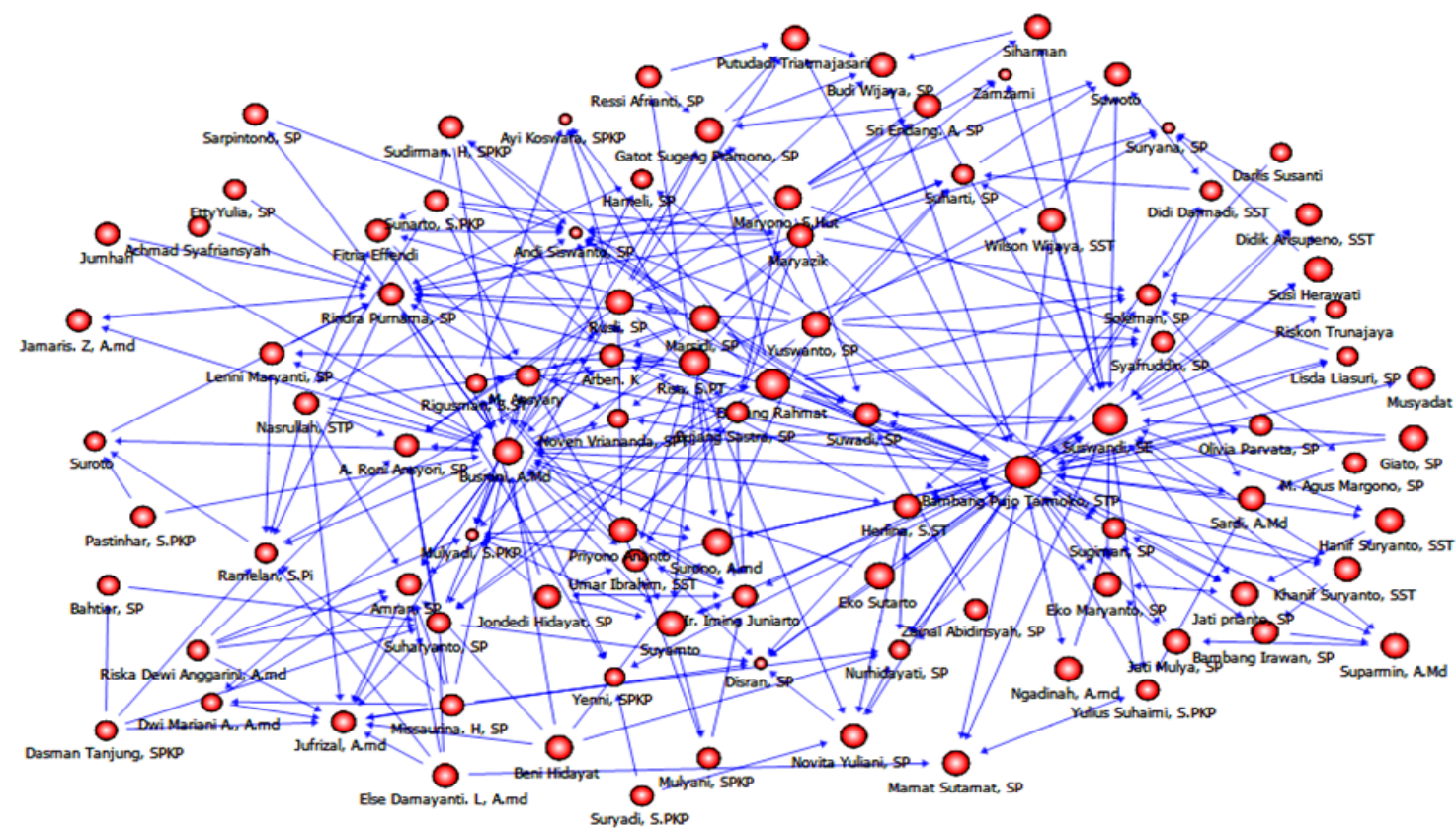

Figure 4. Sociogram out-closeness centrality. 
Seeing the results of the calculation of the value of closeness centrality in Table 3, the information that the value of the highest in-closeness is 0.487 and the value of out-closeness highest is 0.438 . Having closeness centrality index values for in-closeness centrality (In) to the value of $34.479 \%$ and out-closeness centrality (Out) with a value of $36.916 \%$, from the results it can be concluded that from the network with a total of 95 respondents have a value of out-closeness centrality is high, it indicates that the information is scattered (affected/influenced) from one actor to another actor in the network or the trend is more influenced every actor can be easily influenced.

The results of calculation of the value of in-closeness centrality, information obtained actors/nodes that have the highest value of in-closeness among others 1) Busroni, A.Md the value $0.4875,2$ ) Herlina, S.ST value of 0.4119 , and 3 ) Arben. $\mathrm{K}$ value of 0.4019 , thus, the three actors/nodes is an actor who has the ease of disseminating information to the actor/node to another in a network or have the ability to influence the actors/other node in the network.

The results of calculation of the value of out-closeness centrality, information obtained actors/nodes that have the highest value of out-closeness among others 1) Bambang P.T, STP with a value of $0.4381,2$ ) Suswandi, SE with a value of 0.4047 , and 3 ) the value Dadang Rahmat 0.3943 , thus, the three actors/nodes is an actor/node that has easy to be influenced actor/node, in the dissemination of information in the network.

\subsubsection{Betweeness Centrality}

Betweenness approach holds that a person (actor/node) are more central/more important if it as [6,12,20]: 1) a Broker/transmission of information in a network, 2) How much of the information flow is interrupted or have to make a detour if someone stops delivering information or disappear from the network, and 3) To what extent can one control the flow of information because of his position in the network. Actor/nodes that has particularly high betweenness value/central in the network depends on the extent to which the actor/node is needed as a link/

Table 3. Closeness centrality distribution of scores.

\begin{tabular}{ccc}
\hline \multirow{2}{*}{ Measures } & \multicolumn{2}{c}{ Value } \\
\cline { 2 - 3 } & In-Closeness & Out-Closeness \\
\hline Mean & 0.225 & 0.229 \\
Std.Dev. & 0.144 & 0.079 \\
Min & 0 & 0 \\
Max & 0.487 & 0.438 \\
\hline \multicolumn{3}{c}{ Network Closeness Centrality Index } \\
\hline \multicolumn{3}{c}{$34.479 \%$} \\
(In) & $36.916 \%$ \\
\hline
\end{tabular}

nation of information in the network.

The results of the visualizations betweenness centrality can be seen in Figure 5 which is a visualization of the entire data sample is obtained from a total of 95 respondents.

From the above network visualization betweenness centrality calculation results obtained with values ranging from 0 - 0.34, as shown in betweeness values in Table 4.

Centralized network (Network Node Betweenness centrality Index) is low, which amounted to $32.836 \%$. This means showing that structurally, there is no ability/power are great in this network. Actor/nodes as Busroni, A.Md, Bambang P.T, STP and Suswandi, SE seems to have the structural strength to be a facilitator of communication in the network PUAP program. The three actors are also structurally considered "different" from the population. They can also be regarded as "dealmakers" (which makes anything could happen/happen). However, the function of the three actors/nodes such as Supervisor Mitra Tani (PMT) in charge of supervision and advocacy (surveillance, guard and coaching) to the process of growing institutional Gapoktan through Instructor Companion PUAP development, with the ability/power that big in the network is considered to be normal, on the other hand there are actors/nodes with high betweeness value as Herlina, S.ST, Risa, S.PT, Herlina, S.ST and Rindra Purnama, SP, structurally they can be a facilitator for communication within the network implementation PUAP.

\subsection{Mapping Relationships Wake of the Actors in the Implementation of the PUAP Program}

\subsubsection{Mapping Work Area Extension Companion (PP) by Region District}

Rejang Lebong regency is one of regencies in Bengkulu province, consisting of 15 districts including: (A) District Bermani Ulu; (B) Bermani Ulu Raya; (C) Northern Curup; (D) Curup; (E) Eastern Curup; (F) Central Curup (G) South Curup; (H) Selupu Rejang; (I) Sindang Kelingi; (J) Padang Ulak Tanding; (K) Binduriang; (L) Sindang Daratan; (M) Sindang Beliti Ulu; (N) Sindang Beliti Ilir; (O) Kota Padang, with 10 operational areas working Agricultural Extension Center (BPP), Figure 6 is a map of the district administration Rejang Lebong Bengkulu province.

Table 4. Distribution of node betweenness centrality scores.

\begin{tabular}{cc}
\hline Measures & Value \\
\hline Mean & 0.015 \\
Std.Dev. & 0.049 \\
Min & 0 \\
Max & 0.34 \\
Network Node Betweenness Centrality Index & $32.836 \%$ \\
\hline
\end{tabular}




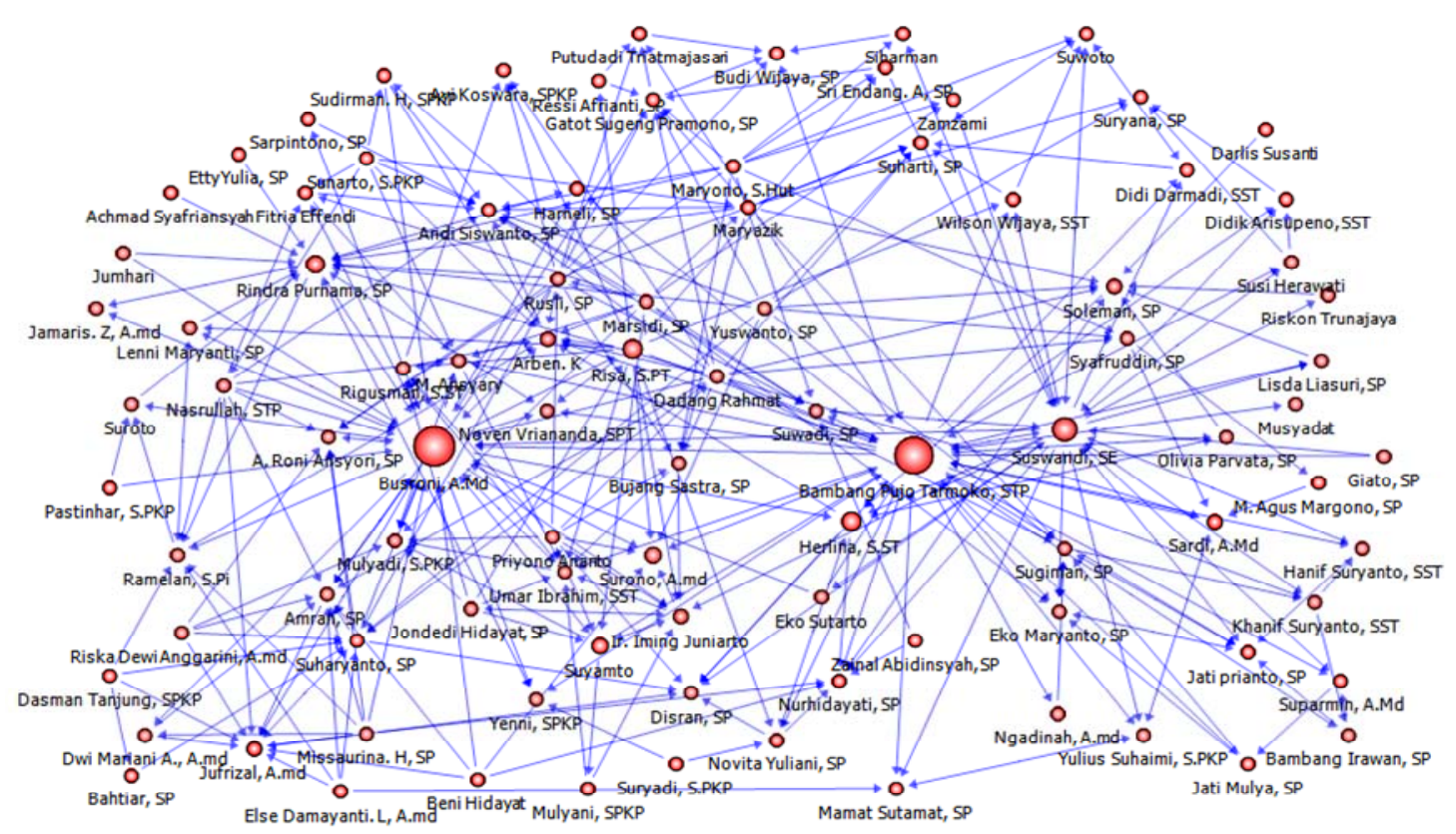

Figure 5. Sociogram betweenness centrality.

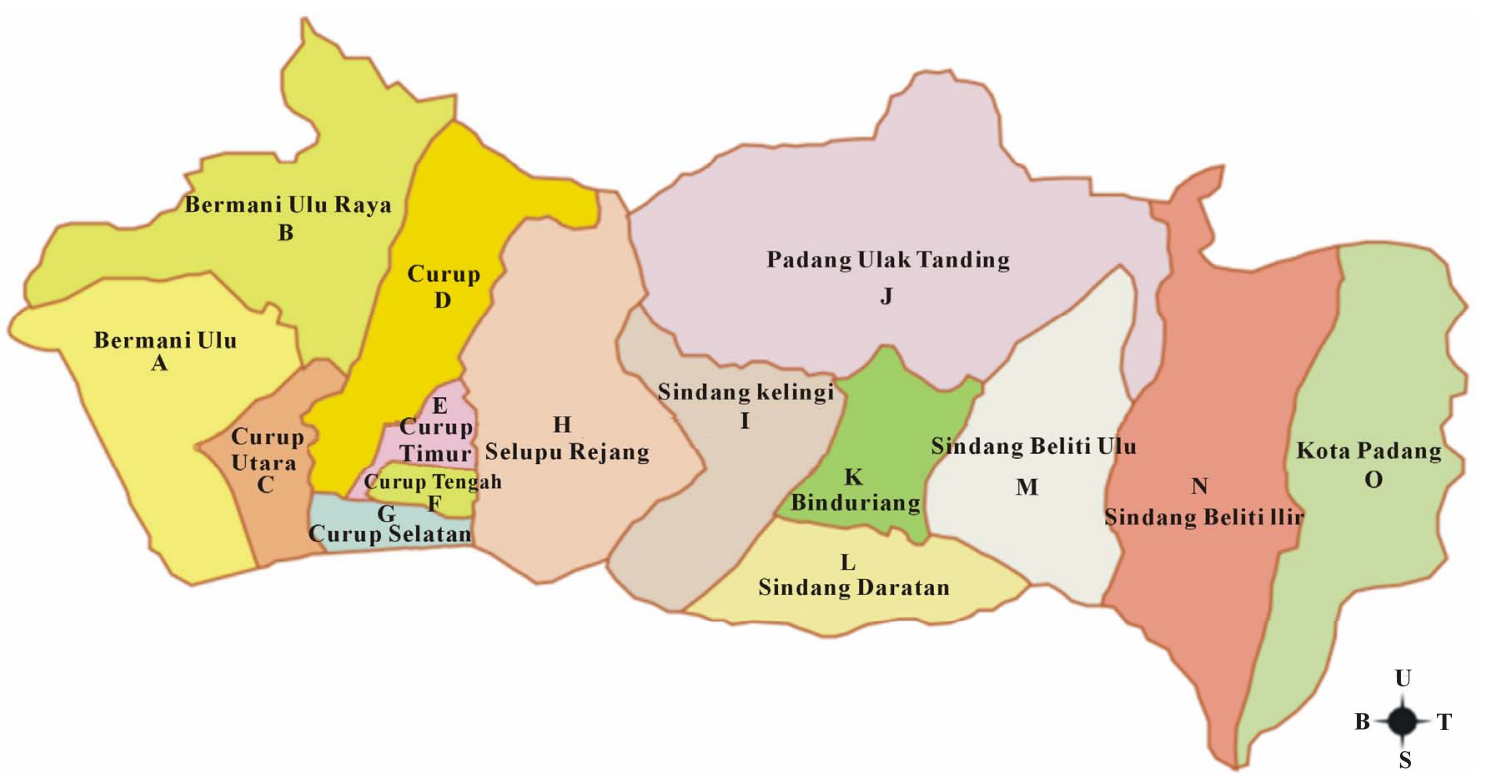

Figure 6. Map of the district administrative region Rejang Lebong Bengkulu province.

In the mapping phase is focused to see how the position of the actors/nodes in geographical space (location, proximity, neighborhood, region) along with their position in the social relationship network, and see the spatial dimension that shows how the form of connectedness that was awakened by actor/nodes in the implementation of PUAP program based on their work area, this stage tries to give an understanding of how the exchange of information and interaction between actors/nodes in the implementation PUAP program by exploring the spatial dimension in a companion extension work area (PP) and aims to determine the efficiency, effectiveness, and productivity of the role actor/nodes in performing their duties. Figure 7 is a visualization Sociogram Degree (Degree Network) is a data visualization of the actors who played companion extension (PP) (the selection of the 95 respondents) in PUAP program consisting of 59 actors, but here the actor who played as a Supervisor Mitra Tani (PMT) eliminated the sample to 56 actors, with the aim of seeing the actor's role and connec tion/node with actor/other node that acts as a companion extension (PP). 


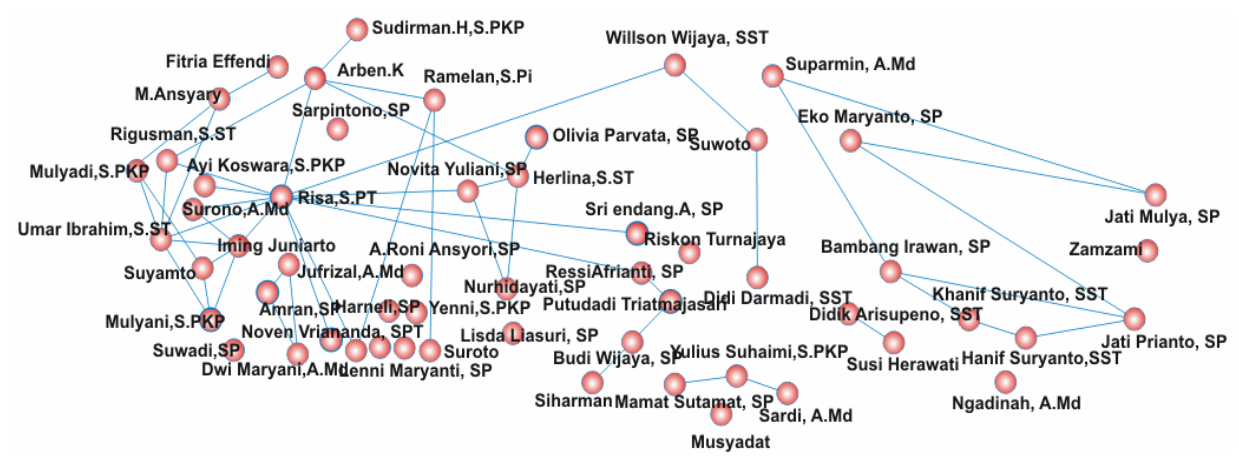

Figure 7. Sociogram Degree of Extension Companion (PP).

Degree-network calculation results obtained information that terbagun relationship between actors/nodes in the network are 62 connectivity, from the calculation of the average degree (mean) value of out-degree and indegree actors in the network is very low, namely: 1.107, seen from the statistical mean value of the out-degree and in-degree in Table 5. This information indicates that each actor/nodes on average only send and receive general information from and to one actor/nodes, based on 56 actors on the network.

From the calculation of degree-network, actor/nodes that have the highest value among the out-degree 1) Risa, S.PT with a value of 12,2 ) Herlina, S.ST with a value of $4,3)$ Ir. Iming Juniarto, Ramelan, S.Pi and Suyamto with a value of 3 , this illustrates that the actors are the most influential in the network because they have the ability to exchange information, actor has an important role in the network because they are the center/hub for exchange of information. The results of the calculation of degree-network, actor/node has in-degree value of which 1) Arben. K to grade 5,2) Umar Ibrahim, SST with a value of 4, and 3) Ir. Iming Juniarto, Jati Prianto, SP and Mulyadi, S.PKP with a value of 3 , actors can be termed as the focal actor of the network and the important actors (prominent actors), this illustrates that many actors/nodes in the network is trying make contact with them.

The position of the actors in a geographical space (location, proximity, neighborhood, region) along with their position in the social relationship network, and see the spatial dimension that shows how the form of connectedness that is built by the actors in the implementation of the program PUAP based their work area can be seen in Figure 8 as follows.

Visualization results can be seen above the understanding of how the exchange of information and interacttion between actors/nodes in the implementation of programs in the district PUAP Rejang Lebong to explore the spatial dimensions of the work area extension companion (PP) based on the sub-districts (working area extension). Of visualization Figure 8 can be seen density linkage actor with other actors working area based companion extension (PP) based on very lace district, repre-
Table 5. Distribution of degree.

\begin{tabular}{|c|c|c|c|c|}
\hline \multirow{2}{*}{\multicolumn{2}{|c|}{ Measures }} & \multicolumn{3}{|c|}{ Value } \\
\hline & & In-Degree & \multicolumn{2}{|c|}{ Out-Degree } \\
\hline \multicolumn{2}{|c|}{ Sum } & 62 & \multicolumn{2}{|c|}{62} \\
\hline \multicolumn{2}{|c|}{ Mean } & 1.107 & \multicolumn{2}{|c|}{1.107} \\
\hline \multirow{2}{*}{\multicolumn{2}{|c|}{$\begin{array}{l}\text { Std. Dev. } \\
\text { Min }\end{array}$}} & 1.097 & \multicolumn{2}{|c|}{1.759} \\
\hline & & 0 & \multirow{2}{*}{\multicolumn{2}{|c|}{0}} \\
\hline \multicolumn{2}{|c|}{$\begin{array}{l}\text { Min } \\
\text { Max }\end{array}$} & 5 & & \\
\hline \multicolumn{2}{|c|}{$\begin{array}{l}\text { \# Of Isolate } \\
\text { \# Of Pendant } \\
\text { Inclusiveness } \\
(\%)\end{array}$} & \multicolumn{3}{|c|}{$\begin{array}{c}12 \\
19 \\
78.571 \%\end{array}$} \\
\hline Isolate & Transmitter & Receiver & Carrier & Ordinary \\
\hline 12 & 11 & 11 & 11 & 15 \\
\hline \multicolumn{2}{|c|}{ Network Density } & \multicolumn{3}{|c|}{0.02} \\
\hline
\end{tabular}

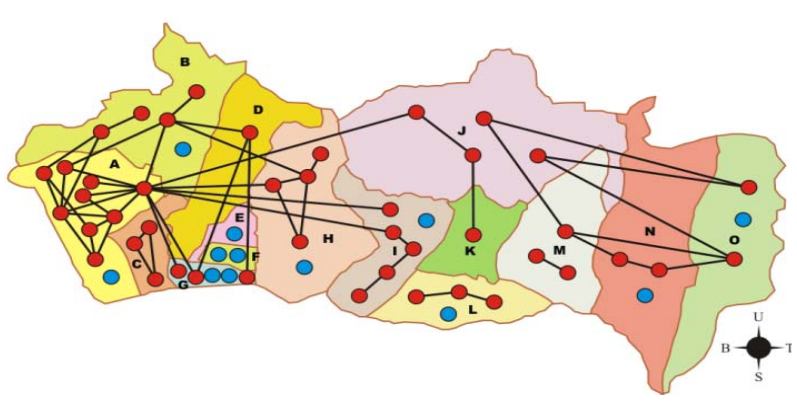

Figure 8. Visualization relationship that is built up from the extension companion (PP) based on the work area districts.

sented by 12 nodes with isolated type (blue nodes) shows that tebangun network between actors/nodes still huge influenced by the role of Supervisor Mitra Tani (PMT).

\subsubsection{Mapping Work Area Extension Companion (PP) Based Agricultural Extension Agency (BPP)}

Rejang Lebong District has 10 operational areas working Agricultural Extension Center (BPP) including 1) Agricultural Extension Center Lubuk Ubar, 2) BPP Mojorejo, 3) BPP PAL VIII, 4) BPP Durian Mas, 5) BPP Kesampe Lama, 6) BPP Bengko, 7) BPP Air Duku, 8) BPP Padang Ulak Tanding, 9) BPP Air Pikat, and 10) BPP Tanjung Agung. This stage saw the spatial dimension that shows 
how the shape of the wake connectedness of actors/nodes in the implementation of the operational program by region PUAP Agricultural Extension Center (BPP) of the companion extension (PP), this stage tries to give an understanding of how the exchange of information and interaction between actors/PUAP nodes in the implementation of the program by exploring the spatial dimension in the area of Operational Agricultural Extension Center (BPP) of the Agricultural Extension (PP) and aims to determine the efficiency, effectiveness, and productivity of the role of actors/nodes in performing their duties. Figure 9 is a visualization of the relationships the actors/ nodes that play a role in PUAP program, comprised of 59 actors, but here the actor who acted as supervisor Mitra Tani (PMT) remains eliminated to 56 actors, with the aim of seeing the actor's role and connection/node with actor/another node that acts as a companion extension (PP).

Visualization results can be seen above the understanding of how the exchange of information and interacttion between actors/nodes in the implementation of the program in the District of Rejang Lebong PUAP Bengkulu Province to explore the spatial dimensions of the operational areas of Agricultural Extension Center (BPP) based on co-working area extension (PP). visualization of Figure 9, can be seen the density and actor linkages with other actors based on the operational area Agricultural Extension Center (BPP), shown with 4 Agricultural Extension Center (BPP) were isolated (BPP Kesambe Lama, BPP Durian Mas, BPP Bengko dan BPP Tanjung Agung), showing that the network that is built up between the actor/node in the operational area BPP is still low, most of connectedness between actors/nodes occurs in the operational areas of BPP, according to where the task of agricultural extension (PP), on the other hand the results of visualization looked actors/ nodes are active as a liaison between the region BPP as (Ressi Afrianti, SP $\rightarrow$ BPP Mojorejo, Wilson Wijaya, SST $\rightarrow$ BPP Padang Ulak Tanding, Novita Yulianti, SP $\rightarrow$ BPP Air Duku, Herlina, S.ST $\rightarrow$ BPP Air Duku, Risa, $\mathrm{S} . \mathrm{PT} \rightarrow$ BPP Air Pikat dan Arben.K $\rightarrow$ BPP Pal VIII), the relationship between actors/nodes between operational areas is still very large BPP influenced by the role of Supervisor Mitra Tani (PMT).

\subsection{Issues in Implementing PUAP Program in District Rejang Lebong}

Based on the findings and identification, were found inhibiting factors that affect the success and sustainability of the program in the district PUAP Rejang Lebong Bengkulu province which has been implemented from 2008, which may be a reference or a reflection of the implementation of the national PUAP program include:

- Technical initial disbursement Direct Community
Assistance (BLM PUAP) to Gapoktan (Association of Farmers Group) are not well targeted election less selective group of beneficiaries, distribution of BLM to Gapoktan average beneficiary of the newly formed farmer groups (formed because there is help).

- No martinet Gapoktan administrative management and farmer groups (Poktan) in managing finances cause Gapoktan not able to coordinate its members.

- The level of awareness of the seriousness of farmers group (Poktan) was low to return loans and supported by the management firm Gapoktan not dicharging their remembers.

- BLM PUAP which has been distributed to Gapoktan (Association of Farmers Group) is used for consumption, understanding members will be distributing to farmers BLM PUAP understood as hiba funds and there is no obligation to return, it is an obstacle to develop and raise funds Rocks Community Direct (BLM PUAP) has been given by the government.

- Support Extension Companion (PP) were deemed less provide direction, breakthrough and application of technological innovation in the development of farmer groups (Poktan), caused by a lack of training, coaching and debriefing to the companion extension (PP) will be the development of new technological innovations.

- Lack of supervision and guidance from both the district level and provincial governments continuously.

- Lack of role Supervisor Mitra Tani (PMT) in conducting surveillance, escort and coaching Gapoktan (Farmers Association) and farmers (Poktan) to improve business performance and the amount of funds to grow into a self-supporting economic institutions farmer or microfinance institutions.

- Political factors and social and cultural views of not being independent and transparent decision-making aid distribution BLM PUAP (because no intervention/pressure from government officials) because of the tendency to prioritize the distribution of funds over family members.

\section{Strategy Performance Improvement PUAP Program in the District of Rejang Lebong}

In line with the development of the implementation of the Rural Agribusiness Development program (PUAP) in Rejang Lebong (RL) district that has run the Bengkulu province started in 2008 with the Direct Community Assistance funds (BLM PUAP) to Gapoktan (Association of Farmers Group) in the form of capital that is used for reinforcement 1) Cultivation of crops, horticulture, livestock, perkebuna, 2) non-farming business includes home industry of agriculture, small-scale marketing and other business-based agriculture. with an approach that 


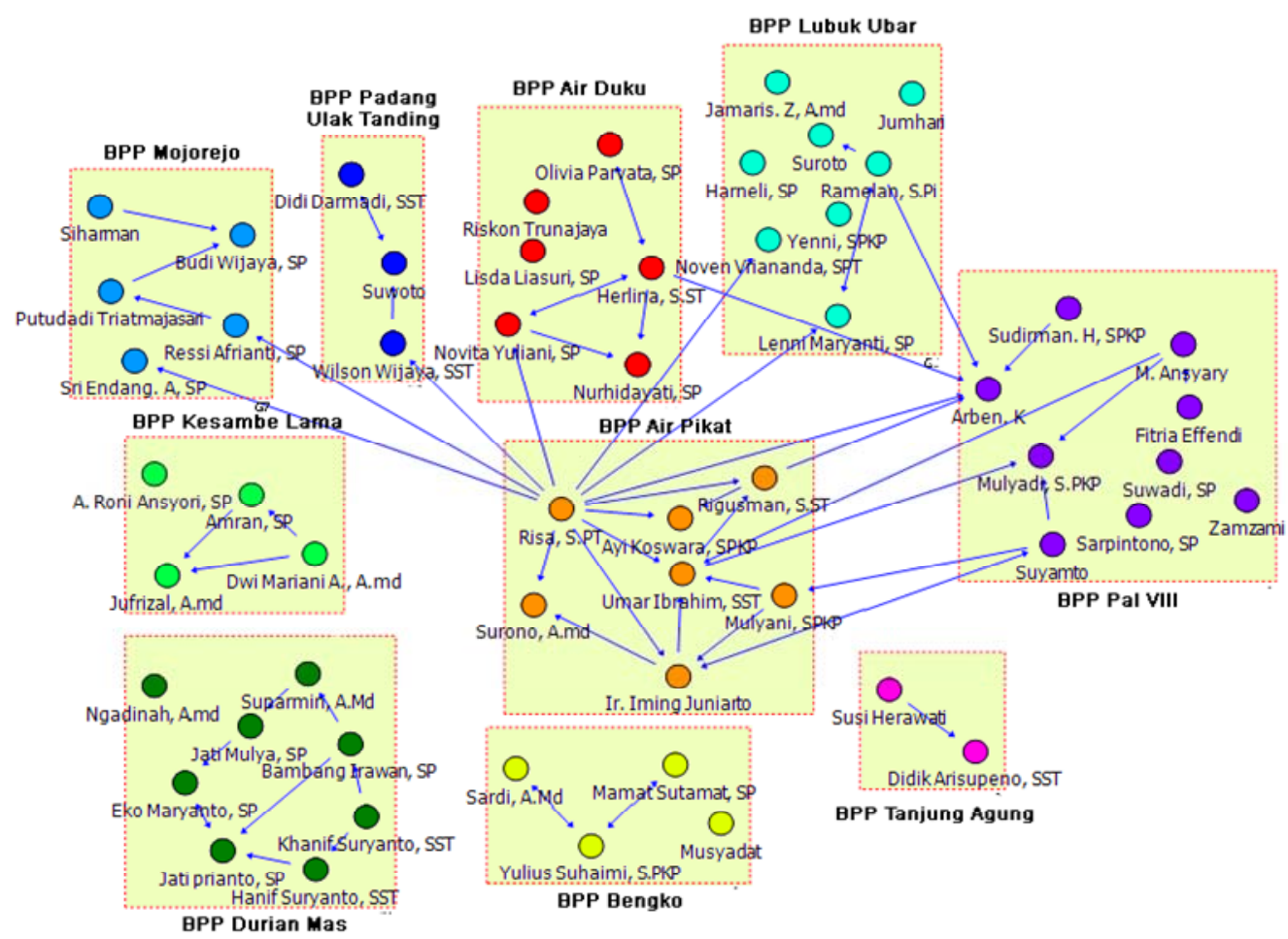

Figure 9. Visualization relationship that is built up from the extension companion (PP) based on the work area agricultural extension agency (BPP).

has been implemented is expected to produce a resultant significant, on the other hand analyzes aimed at understanding the role of actor or Connectivity connectedness of actors in the network (all stakeholders PUAP program), and the role of actors in the network are relevant measures in order to develop a strategy and planning phase of the program of work of PUAP for the sustainability of the program in the future (finding the right strategy) with the aim of increasing the performance of the program in the District of Rejang Lebong PUAP Bengkulu province, and can be a reference or a reflection of the implementation of the national program in Indonesia PUAP.

Departing from Thought network (network thinking), that a contributor to the views and contributions related to social power (social power), that an actor who has the 'power,' the actor has a 'dominance' for the other actors. Power/power of an actor is the dependence of other actors associated with it, and vice versa. The role and contribution of an actor in the implementating of program PUAP as like such Busroni, A.Md (PMT), Bambang PT (PMT), STP, and Suswandi, SE (PMT) need to be improving and expanded due to the role of them are three actors as Supervisor Mitra Tani (PMT) whose role is to conduct supervision and advocacy processes to Gapoktan institutional growth through Extension Companion (PP) as well as provide guidance for Gapoktan PUAP who have managed to improve business performance and the amount of funds that grow up to be self-supporting economic institutions farmer or microfinance institutions can be a rationalization of the network (social network) have formed social power and that there is an interaction of social capital is good, and should be seen back role, contribution of actors who turned up (having the potential power/influence) of social network analysis as Rindra Purnama, SP (Head $\rightarrow$ BPP of Ubar Lubuk), Andi S, SP (Head $\rightarrow$ BPP Pal VIII), Arben. K (Extension Companion $\rightarrow$ Pal VIII) that the future needs to be improved coordination and influence to improve the implementation of the PUAP program especially at the institutional level, work area Agricultural Extension Center (BPP), Table 6 describes the actors who have roles and contributions (social power) on the PUAP programin Rejang Lebong district (RL).

As an actor who has the potential and is quite influential in the network (network), as a result of the ability and willingness to exchange information, based on a table of 6 they have the structural strength to be a facilitator of communication, thus, they are the dominant actors and an important actor in the development program PUAP Rejang Lebong district, assuming that the entity information is a chance (opportunity) in order to improve performance, it is within the framework of the implementation of improvement programs such as empowerment PUAP Gapoktan, working capital for productive activeties and community empowerment through participatory, 
Table 6. Data actors with power, influence and domination that has potential.

\begin{tabular}{cc}
\hline Power & Potential \\
\hline Busroni, A.Md & Rindra Purnama, SP (BPP-Lubuk Ubar) \\
(PMT) & Andi Siswanto, SP (BPP-Pal VIII) \\
Bambang, STP & Amran, SP (BPP-Kesambe Lama) \\
(PMT) & Arben. K (BPP-Pal VIII) \\
Suswandi, SE (PMT) & Risa, ST (BPP-Air Pikat) \\
& Herlina, S.ST (BPP-Air Duku) \\
\hline
\end{tabular}

facilitated needs related to information- critical information needed to improve performance such as farm produce marketing opportunities (market opportunities) and the application of technological innovation in the development effort of a group of farmers (need to increase training, coaching and mentoring). In addition, the relationships between actors in the network implementation occurred in Regency PUAP Rejang Lebong (RL) have a tendency to be a weak correlation (weak ties).

\section{Conclusions}

Based on the analysis and discussion are carried out to answer the research question, it can be concluded in this study such things as:

1) The relationship between actors that occur in the network (network) implementation of the program in the District of Rejang Lebong PUAP Bengkulu province has the tendency is weak relationships (weak ties).

2) actors who have a role, influence and contribution in the implementation of programs in the district PUAP Rejang Lebong (RL), such Busroni, A.Md (PMT), Bambang PT (PMT), STP, and Suswandi, SE (PMT) should improved and developed due to the role of the three actors as Penyella Mitra Tani (PMT) is expected to play an important role in the supervision and advocacy process of institutional growth and its extension to Gapoktan Companion (PP) work together to provide guidance Gapoktan PUAP who have managed to improve the performance of the business and the amount of funds self-reliance so that farmers grow into an economic institution or microfinance institutions can be a rationalizetion that social networks have formed social forces and interactions are social capital (social capital) is good.

3)Please see the roles and contributions of other actors who appear (which has the potential power/influence) of social network analysis as Rindra Purnama, SP (Head $\rightarrow$ Lubuk Ubar BPP), Andi Siswanto, SP (Head $\rightarrow$ BPP Pal VIII), Amran, SP (Extension Companion $\rightarrow$ BPP Kesambe Lama), Arben. K (Extension Companion $\rightarrow$ BPP Pal VIII), Umar Ibrahim, SST (Extension Companion $\rightarrow$ BPP Air Pikat), Herlina, S.ST (Extension Companion $\rightarrow$ BPP Air Duku) and Risa,ST (Extension Companion $\rightarrow$ BPP Air Pikat) the future needs to be improved coordination, role and influence (social power) to improve the implementation of PUAP program at the institutional level, particularly in the work area Agricultural Extension Center(BPP).

\section{REFERENCES}

[1] C. Kadushin, "Introduction to Social Network Theory," Boston, 2004

[2] R. Agusyanto, "Fenomena Dunia Mengecil: Rahasia Jaringan Sosial," Institute Antropologi Indonesia, Jakarta, 2010 .

[3] E. M. Daly and M, Haahr, "Social Network Analysis for Routing in Disconnected Delay-Tolerant," ACM, New York, 2007.

[4] W. De Nooy, A. Mrvar and V. Batagelj, "Exploratory Network Analysis with Pajek," Cambridge University Press, New York, 2005.

[5] S. Pryke, "Analysing Construction Project Coalitions: Exploring the Application of Social Network Analysis," Construction Management and Economics, Vol. 22, No. 8, Routledge, London, 2004. doi:10.1080/0144619042000206533

[6] B. Wellman, “An Electronic Group Is Virtually a Social Network," In: S. Kiesler, Ed., Culture of the Internet, Lawrence Erlbaum, Mahwah, 1997, pp. 179-205.

[7] K. J. Liao and H. H. Xiong, "Study on Knowledge Sharing of Community of Practice Based on Social Network Perspective," iBusiness, 2011, pp. 283-286.

[8] O. Serrat, "Social Network Analysis, Knowledge Solutions," Asian Development Bank (ADB), Mandaluyong City, 2009.

[9] R. A. Hanneman and R. Mark, "Introduction to Social Network Methods," University of California, Riverside, 2005. http://faculty.ucr.edu/ hanneman/

[10] J. L. Moreno, "The Sociometry Reader," The Free Press, Glencoe, Illinois, 1960, p. 35

[11] M. G. Everett and S. P. Borgatti, "Extending Centrality," In: P. J. Carrington, J. Scott and S. Wasserman, Eds., Models and Methods in Social Network Analysis, Cambridge University Press, New York, 2005, pp. 57-76.

[12] P. J. Carrington, J. Scott and S. Wasserman, "Models and Methods in Social Network Analysis," Cambridge University Press, New York, 2005

[13] S Wasserman and K. Faust, "Social Network Analysis: Methods and ACElications," Cambridge University Press, New York, 1994 doi:10.1017/CBO9780511815478

[14] P.-C. Lee, H.-N. Su and F.-S. Wua, "Quantitative Mapping of Patented Technology-The Case of Electrical Conducting Polymer Nanocomposite," Technological Forecasting \& Social Change, Vol. 77, 2010, pp. 466478. doi:10.1016/j.techfore.2009.08.006

[15] H. Leitner, E. Sheppard and K. M. Sziarto, "The Spatialities of Contentious Politics," Transactions of the Institute of British Geographers, Vol. 33, No. 2, 2008, pp. 157 172. doi:10.1111/j.1475-5661.2008.00293.x 
[16] A. Trauger, "Social Agency and Networked Spatial Relations in Sustainable Agriculture," Royal Geographical Society, London, 2009, pp. 117-128

[17] M. Granovetter, "Threshold Models of Collective Behavior," American Journal of Sociology, Vol. 83, No. 6, 1978, pp. $1420-1443$. doi: $10.1086 / 226707$

[18] M. R. Steven, F. Colin and E. T. George, "Spatializing Social Networks: Using Social Network Analysis to In- vestigate Geographies of Gang Rivalry, Territoriality, and Violence in Los Angeles," Annals of the Association of American Geographers, Taylor \& Francis, LLC., 2009

[19] Y. Doytsher, B. Galon and Y. Kanza, "Querying SocioSpatial Networks on the World-Wide Web," International World Wide Web Conference Committee, Lyon, France, 2012, (IW3C2), ACM 978-1-4503-1229-5/12/04.

[20] T. Maksim and A. Kouznetsov, "Social Network Analysis for Startups,” O’Reilly Media, Inc., Sebastopol, 2011. 